\title{
Linking habitat modification to catastrophic shifts and vegetation patterns in bogs
}

\author{
Maarten B. Eppinga · Max Rietkerk • \\ Martin J. Wassen · Peter C. De Ruiter
}

Received: 28 February 2006/ Accepted: 15 May 2007/Published online: 12 June 2007

(C) Springer Science+Business Media B.V. 2007

\begin{abstract}
Paleoecological studies indicate that peatland ecosystems may exhibit bistability. This would mean that these systems are resilient to gradual changes in climate, until environmental thresholds are passed. Then, ecosystem stability is lost and rapid shifts in surface and vegetation structure at landscape scale occur. Another remarkable feature is the commonly observed self-organized spatial vegetation patterning, such as string-flark and maze patterns. Bistability and spatial selforganization may be mechanistically linked, the crucial mechanism being scale-dependent (locally positive and longer-range negative) feedback between
\end{abstract}

M. B. Eppinga $(\bowtie) \cdot$ M. Rietkerk ·

M. J. Wassen - P. C. De Ruiter

Department of Environmental Sciences, Copernicus

Institute, Utrecht University, P.O. Box 80115,

3508 TC Utrecht, The Netherlands

e-mail: M.Eppinga@geo.uu.nl

M. Rietkerk

e-mail: M.Rietkerk@geo.uu.nl

M. J. Wassen

e-mail: M.Wassen@geo.uu.nl

P. C. De Ruiter

e-mail: Peter.deRuiter@wur.nl

Present Address:

P. C. De Ruiter

Soil Science Centre, Wageningen University,

P.O. Box 47, 6700 AA Wageningen, The Netherlands

e-mail: Peter.deRuiter@wur.nl vegetation and the peatland environment. Focusing on bogs, a previous model study shows that nutrient accumulation by vascular plants can induce such scale-dependent feedback driving pattern formation. However, stability of bog microforms such as hummocks and hollows has been attributed to different local interactions between Sphagnum, vascular plants, and the bog environment. Here we analyze both local and longer-range interactions in bogs to investigate the possible contribution of these different interactions to vegetation patterning and stability. This is done by a literature review, and subsequently these findings are incorporated in the original model. When Sphagnum and encompassing local interactions are included in this model, the boundaries between vegetation types become sharper and also the parameter region of bistability drastically increases. These results imply that vegetation patterning and stability of bogs could be synergistically governed by local and longerrange interactions. Studying the relative effect of these interactions is therefore suggested to be an important component of future predictions on the response of peatland ecosystems to climatic changes.

Keywords Alternate stable states - Bog model . Climate change $\cdot$ Self-organization $\cdot$ Vegetation patchiness $\cdot$ Vegetation switches 


\section{Introduction}

Northern peatlands occupy less than $2 \%$ of the land surface yet contain about $30 \%$ of the total terrestrial carbon pool (Gorham 1991), and are located in the altitudes expected to undergo the greatest increase in temperature and precipitation in the next decades (Houghton et al. 1995). Higher temperatures and longer thaw seasons may alter internal peatland dynamics in a way that increases emission of carbon dioxide and methane from these systems (Bridgham et al. 1995). Therefore concern has risen that peatlands may switch from sinks to sources of atmospheric carbon under such changing climate (Yu et al. 2001). An important factor controlling the rate of carbon sequestration is the peatland surface structure (Belyea and Malmer 2004). This structure comprises distinct microforms (order of magnitude: $\mathrm{m}$ ), ranging from wet depressions (hollows or pools) to dry hummocks (e.g., Belyea and Clymo 2001). Focusing on peatland bogs, the hollows are usually dominated by species of the genus Sphagnum growing with sedges, while vascular plants mostly grow on the hummocks, coexisting with different species of Sphagnum (Wallén et al. 1988; Van Breemen 1995). Both these functional groups are actively modifying the bog habitat and thereby bog hydrology and peat accumulation.

The aim of this synthesis article is to gain insight in the possible effect of habitat modification by Sphagnum and vascular plants on peatland dynamics and also spatial self-organization, especially focusing on peatland bogs. First we discuss how paleoecological studies indicate that peatland dynamics may be governed by catastrophic shifts, and that selforganized vegetation patchiness might indicate proximity to such shifts. Then we review literature synthesizing bog habitat modification by Sphagnum and vascular plants. Subsequently, habitat modification is linked to spatial self-organization of bogs. As an illustration, we include habitat modification by Sphagnum and vascular plants in a simple and generic way in the analytical bog model of Rietkerk et al. (2004a), to illustrate its effect on bog dynamics and spatial self-organization. The results will be discussed from the perspective of the role of habitat modification in the response of bogs to climate change.

\section{Catastrophic shifts in peatlands}

A paleoecological study revealed that the current microtopography of hummocks and hollows of a Scottish mire has persisted for 5,000 years (Moore 1977). In an Irish mire, Walker and Walker (1961) found stratigraphic evidence that microforms had remained at the same position over time. Similar conclusions are drawn from other study sites (e.g., Sjörs 1961; Casparie 1972; Boatman and Tomlinson 1973; Frenzel 1983), and there is a general agreement that these different microforms are remarkably resilient to changes in environmental conditions (Belyea and Clymo 2001; Nungesser 2003), such as climate change.

However, this resilience is lost when changes in climate pass environmental thresholds, at which the peatland surface structure may abruptly shift to another stable state, with a different microstructure dominating the landscape (Belyea and Malmer 2004). If hollows dominate the landscape, it can be characterized as open treeless mire, while domination of hummocks with trees can be regarded as mire woodland (e.g., Alexandrov and Logofet 1994; Ohlson et al. 2001). Rapid transitions from open treeless mires to mire woodlands have been reported in paleoecological studies (see references in: Frankl and Schmeidl 2000; Ohlson et al. 2001). However, the reverse transition from mire woodland to treeless mire can also occur (Clymo and Hayward 1982; Svensson 1995; Van Breemen 1995; Ohlson et al. 2001). These transitions in microforms and vegetation also result in rapid changes in decomposition rates and carbon sequestration, stressing the urgent need for a better understanding of environmental thresholds in peatlands, and the way its surface structure and vegetation respond to climatic changes (Belyea and Malmer 2004).

A growing body of research suggests that these kinds of nonlinear responses of ecosystems to gradual changes in environmental conditions are associated with the occurrence of alternate stable ecosystem states (Scheffer et al. 2001). This concept was introduced by Lewontin (1969), and is still an issue of considerable interest and debate (Bertness et al. 2002). Alternate stable states mean that given the same set of environmental conditions, an ecosystem has more than one possible stable structure. Each 
stable structure has its own basin of attraction, meaning a certain range of ecosystem states that will always develop toward this stable structure (Lewontin 1969). Consequently, if such stable structure is reached, the ecosystem is resilient to perturbations within that basin of attraction.

However, changes in environmental conditions can alter the sizes of basins of attraction. Such changes may decrease a basin of attraction until it vanishes. When this point is reached, the ecosystem will be drawn toward another stable structure. This threshold where the basin of attraction of the current ecosystem equilibrium disappears is known as a catastrophic bifurcation point (Kuznetsov 1995; Scheffer and Carpenter 2003). Ecologists have long recognized that gradual changes in environmental conditions can cause abrupt changes in ecosystems (Carpenter 2001). The passing of a catastrophic bifurcation point can explain such "Big effects from small causes" (Ricker 1963). These "Big effects" are referred to as catastrophic shifts in ecosystem states (Scheffer et al. 2001).

The term catastrophic shift comes from catastrophe theory. Catastrophe theory originated as a branch of mathematics studying bifurcations between different equilibria due to gradual changes (Thom 1975; Zeeman 1976). The theory is also useful for studying ecosystems with alternate stable equilibria (Loehle 1989). It is important to note that a catastrophic shift of an ecosystem into a different equilibrium does not necessarily imply a disaster or dramatic event, but it refers to the nature of the change. The term can therefore be a bit confusing, because sometimes the occurrence of a catastrophic shift is desired, and therefore stimulated (e.g., Meijer and Hosper 1997).

The existence of alternate stable ecosystem states and catastrophic shifts implies that the state of an ecosystem cannot only be explained by the current environmental conditions, because the current ecosystem state also depends on its history. This phenomenon is known as hysteresis. Reversing a catastrophic shift is not achieved by simply restoring the environmental conditions that prevailed just before the shift took place because of such hysteretic dynamics. Restoring an ecosystem that has catastrophically degraded may therefore be very difficult or expensive (Carpenter 2001), if it is possible at all. Therefore, it is desirable to know whether ecosystems are close to a catastrophic shift. Unfortunately, catastrophic shifts are typically unpredictable, and "early warning signals" of approaching catastrophic change are difficult to obtain (Scheffer et al. 2001).

\section{Vegetation patterning in peatlands}

Recently, it has been suggested that the formation of self-organized vegetation patterns in peatlands indicate proximity to catastrophic shifts (Rietkerk et al. 2004b). Interesting observations in this respect are the rapid transition from a homogeneous hummock state into the current patterned state of a Swedish bog (Belyea and Malmer 2004), and the loss of surface patterning within 50 years in another Swedish mire (Gunnarsson et al. 2000). Self-organized patchiness in peatlands consists of a spatially regular two-phase mosaic of typical hummock and hollow vegetation (Rietkerk et al. 2004a). Patterned peatlands have been observed in North America (e.g., Heinselman 1963), Europe (e.g., Sjörs 1961), Asia (e.g., Sakaguchi 1980) and also on the Southern Hemisphere (Mark et al. 1995), including tropical mires (Backéus 1989). Two types of patterns $\left(10^{2}-10^{3} \mathrm{~m}\right)$ can be observed (Sjörs 1983; Wallén et al. 1988; Rietkerk et al. 2004a; Fig. 1): string and flark patterns on slopes and maze patterns on relatively flat mire parts.

String and flark patterns consist of linearly merged hummocks (strings) alternating with linearly merged hollows (flarks), oriented along the topographic contours of peatland slopes. The origin of string and flark patterns has received considerable attention during the last century (Charman 2002), which has resulted in many hypotheses involving physical and biotic processes to explain the development of this peatland patterning (Seppäla and Koutaniemi 1985; Glaser 1992; Belyea and Lancaster 2002). We restrict our discussion to biotic processes since these are currently thought to be governing peatland patterning (Seppäla and Koutaniemi 1985; Charman 2002).

A detailed hypothesis on initiation of flarks was derived from stratigraphical analyses in North America (Foster et al. 1983; Foster and King 1984; Glaser 1992). It consists of three elements: (1) Initial accumulation of peat, converting channeled water flow into sheet flow; (2) Amplification of the surface microtopography because of slower peat accumulation in hollows as compared to hummocks, and higher resistance of hollows to infiltration. Adjacent 

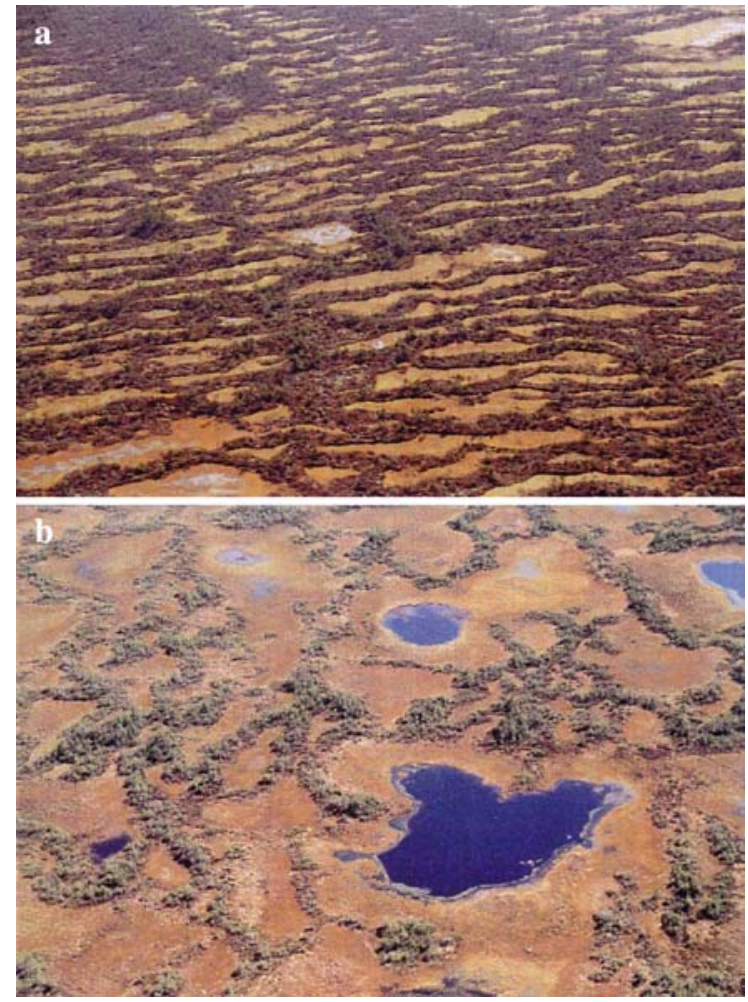

Fig. 1 Photographs of hummock-hollow complexes on the slope (a) and the central part (b) of a watershed bog in the great Vasyugan area, Siberia (Courtesy W. Bleuten and E.D. Lapshina). Hummocks are covered with dwarf shrubs, Pinus sylvestris, $P$. sibirica and Sphagnum fuscum, hollows are occupied by $S$. balticum, S. majus, S. jensii, S. papillosum, Carex limosa, and Rhynchospora alba (Semenova and Lapshina 2001; E.D. Lapshina, pers. comm.)

hollows merge into linear flarks; (3) Subsequent enlargement of flarks. Water chemistry (Glaser 1992) and vegetation changes (Glaser et al. 1981; Glaser 1987, 1992) in North American patterned fens could be explained with this hypothesis. Spatial analysis of a bog pool complex in Scotland confirmed most elements of this hypothesis (Belyea and Lancaster 2002).

Related to this hypothesis is the idea that differences in hydraulic conductivity may induce pattern formation. The hydraulic conductivity of hummocks is lower than that of hollows (Ivanov 1981); therefore water flow tends to pond up behind hummocks, causing hollow formation upslope (Couwenberg 2005, and references therein).

Other studies focus on the initiation of strings, emphasizing the importance of spring floods in string formation (Sakaguchi 1980; Seppäla and Koutaniemi 1985). During these floods slush and plant remains are transported toward elevations on the mire surface, thereby amplifying the surface microtopography.

These hypotheses have in common that they suggest that topographic differences on the peatland slope are amplified by local feedbacks between hydrology, peat accumulation, and vegetation. As a result, hummocks and hollows develop in the landscape. Given the anisotropy (that is unidirectional water flow) on peatland slopes, linear features will develop over time.

Maze patterns on relatively flat mire parts consist of merged hummocks that are star or net-like. These patterns have been reported less frequently in literature, but they cover extensive areas in the Vasyugan area in Siberia for example (Semenova and Lapshina 2001; Rietkerk et al. 2004a; Fig. 1). The formation of spatially regular maze patterns on flat mire parts cannot be fully explained by the local feedbacks described above, because unidirectional water flow is lacking (Rietkerk et al. 2004a). A putative mechanism inducing maze patterning is accumulation of nutrients under and near vascular plants through the advective transport of nutrients driven by transpiration of vascular plants (Rietkerk et al. 2004a; Wetzel et al. 2005).

The crucial mechanisms linking self-organized patchiness to catastrophic shifts are scale-dependent (that is locally positive and longer-range negative) feedbacks between the environment and plant species that actively modify this environment (Rietkerk et al. 2004b). This scale dependency arises when plants withdraw resources from their surroundings, leading to local resource accumulation, and longer-range resource depletion. Hence there is a local positive effect, and a longer-range negative effect. Nutrient accumulation by vascular plants is an example of such a scale-dependent feedback.

However, several models (Logofet and Alexandrov 1988; Alexandrov and Logofet 1994; Hilbert et al. 2000; Belyea and Clymo 2001), field experiments (Belyea and Clymo 2001) and studies on string-flark patterning (Foster et al. 1983; Glaser 1992) suggest that the observed stability of peatland microforms results from more local feedbacks between hydrology and peat accumulation, resulting in alternate stable microstates of hummocks and hollows. In the following we speak of local processes 
when there is a short-range self-enforcing effect that does not induce effects on a longer range.

Focusing our current study on bogs, both the hollow-species of Sphagnum, from here referred to as Sphagnum, (Clymo and Hayward 1982; Svensson 1995; Van Breemen 1995) and vascular plants (most research focusing on Pinus sylvestris; Frankl and Schmeidl 2000; Ohlson et al. 2001) actively modify their habitat and thereby bog hydrology and peat accumulation. Therefore, we will now summarize findings in literature providing a more detailed overview of the habitat modification by these two functional groups.

\section{Bog habitat modification by Sphagnum and vascular plants}

The pivotal environmental variables determining growth of Sphagnum and vascular plants in bogs are temperature, light availability, nutrient availability, $\mathrm{pH}$, and the level of the water table (Malmer 1962; Clymo 1970; Ivanov 1981; Clymo and Hayward 1982; Ingram 1983; Hayward and Clymo 1983; Backéus 1985; Rydin and McDonald 1985; Wallén et al. 1988; Økland 1990; Alexandrov and Logofet 1994; Belyea 1996; Gunnarsson and Rydin 1998; Frankl and Schmeidl 2000; Limpens et al. 2003; Nungesser 2003). The physiological characteristics of both Sphagnum and vascular plants drive ecosystem processes that change the pivotal environmental variables of bog ecosystems in a way that favors their own functional group, but disfavors the other functional group (Fig. 2).

It is important to note that neither functional group forms pure stands in bog ecosystems; the hollows are usually dominated by Sphagnum growing with sedges, while different species of Sphagnum occur on the higher vascular plant dominated hummocks. However, we assume that the effect of each functional group on the environment is determined by the effect of its dominant species. This simplifying assumption is made to enable the subsequent coupling of our findings to an analytical mathematical model. The effect of Sphagnum and vascular plants on the bog environment will now be discussed in more detail for each of the five pivotal environmental variables.
Light availability

Using different strategies (Clymo and Hayward 1982; Svensson 1995; Fig. 2), both Sphagnum and vascular plants shape light availability in a way that suppresses the other functional group. Extensive Sphagnum growth hampers establishment of vascular plants (Ohlson et al. 2001), because it forms a thick carpet that overgrows small vascular plants (Malmer et al. 2003). On the other hand, when vascular plants have successfully established and reach above the Sphagnum carpet, it decreases Sphagnum development through shading and burial by aboveground litter (Hayward and Clymo 1983; Wallén et al. 1988; Malmer et al. 1994; Lamers et al. 2000; Berendse et al. 2001; Malmer et al. 2003). It can be concluded that Sphagnum and vascular plants modify the environment in opposite directions. As a result, interspecific competition for light exceeds intraspecific competition. Also, dominance of the functional groups may alter during the growing season.

Acidity (pH)

Sphagnum is considered an important source of acidity in bog waters (Siegel et al. 2006). It has long been suggested that the acidifying capability of Sphagnum stems from its high cation-exchange capacity, because of the considerable amounts of polyuronic acids in the tissue (e.g., Clymo 1964; Clymo and Hayward 1982; Van Breemen 1995). However, more rigorous geochemical studies strongly suggest that organic acids are the primary acidifying agent in bogs (Gorham et al. 1986; Reeve et al. 1996; Glaser et al. 2004; Siegel et al. 2006). Organic acids are believed to result from humification of Sphagnum (Hemond 1980), leading to a local decrease in mire water $\mathrm{pH}$ (Bragazza et al. 1998). It can thus be concluded that Sphagnum actively acidifies its environment, which is unfavorable for vascular plant growth (Van Breemen 1995). Thereby Sphagnum negatively affects vascular plants.

Water table

Compared to vascular plants, Sphagnum is less productive (Verry and Urban 1992). Therefore, relatively small yearly precipitation excess is needed for Sphagnum dominated bogs to maintain or 


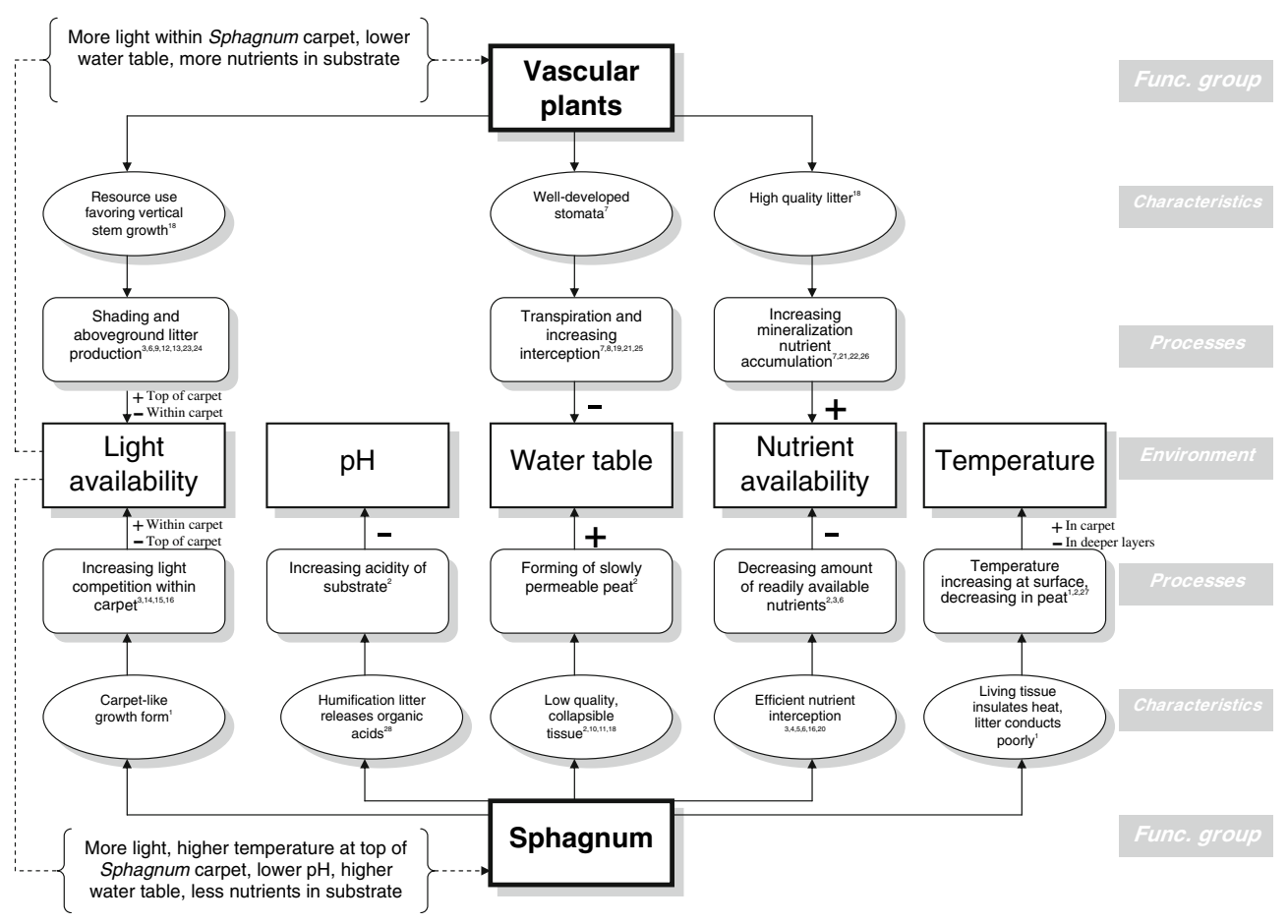

Fig. 2 Habitat modification by Sphagnum and vascular plants in bogs. The ovals show the main functional characteristics of the two functional groups. The rounded rectangles show the resulting ecological processes. Solid arrows show relations and effects, the dashed arrows the feedbacks. The pivotal environmental variables are depicted in the rectangles. Minus signs mean a decreasing/lowering effect, plus signs an increasing/ stimulating effect. Both plus and minus signs mean that the effect differs at the top or within the Sphagnum carpet (in case of light availability) or differs between the Sphagnum carpet and lower peat layers (in case of temperature). References; 1 : Clymo and Hayward (1982) 2: Van Breemen (1995) 3: Malmer

decrease the distance between the bog surface and the water table. Moreover, Sphagnum litter decays slowly and is easily collapsible (Coulson and Butterfield 1978; Johnson and Damman 1993; Van Breemen 1995; Hobbie 1996), meaning that it stimulates the formation of peat with small porosity. This means that little water is needed for this low permeable peat to become waterlogged, so this characteristic of Sphagnum also promotes a higher water table (Van Breemen 1995). On the other hand, vascular plants stimulate a lowering of the water table by increasing the rate of evapotranspiration (Ingram 1983; Marschner 1995; Frankl and Schmeidl 2000; Rietkerk et al. 2004a), and the canopy of trees diminishes the amount of precipitation that reaches the surface (Rutter 1963). It can thus be concluded that Sphagnum et al. (2003) 4: Rydin and Clymo (1989) 5: Clymo (1970) 6: Malmer et al. (1994) 7: Marschner (1995) 8: Ingram (1983) 9: Wallén et al. (1988) 10: Coulson and Butterfield (1978) 11: Johnson and Damman (1993) 12: Hayward and Clymo (1983) 13: Murray et al. (1993) 14: Backéus (1985) 15: RedboTorstensson (1994) 16: Svensson (1995) 17: Gunnarsson and Rydin (1998) 18: Hobbie (1996) 19: Frankl and Schmeidl (2000) 20: Heijmans et al. (2002) 21: Rietkerk et al. (2004a) 22: Belyea and Clymo (2001) 23: Lamers et al. (2000) 24: Berendse et al. (2001) 25: Rutter (1963) 26: Fitter and Hay (1983) 27: Williams (1970) 28: Hemond (1980)

promotes submergence, while vascular plant growth stimulates water table drawdown. Both functional groups are thus modifying the environment but in opposite directions, thereby negatively affecting each other. If a functional group increases in density, it modifies its environment toward better growing conditions for itself and creates worse conditions for the competing functional group. Moreover, if a functional group increases in density, it can better counteract adverse effects of the opposite modifications by the competing functional group.

Nutrient availability

The competition for nutrients in bogs is asymmetric, because Sphagnum acts as an effective filter 
intercepting and effectively recycling all nutrient inputs from atmospheric deposition (Clymo 1970; Rydin and Clymo 1989; Malmer et al. 1994; Svensson 1995; Heijmans et al. 2002; Malmer et al. 2003), while vascular plants mainly depend on nutrients that are released via mineralization of the peat (Malmer et al. 1994; Malmer et al. 2003). Apart from the effective interception, Sphagnum peat sequesters mineral nutrients from the acrotelm, and the low quality litter input of Sphagnum reduces mineralization rates in this layer (Malmer et al. 1994; Van Breemen 1995; Malmer et al. 2003) On the other hand, the previously discussed lowering effect on water table height by vascular plants, together with their deposit of high quality litter, promotes an increase in mineralization rate (Hobbie 1996; Belyea and Clymo 2001). Furthermore, vascular plants may attract and accumulate nutrients from the surrounding environment through advective transport by groundwater, which is driven by the active transpiration of vascular plants (Marschner 1995; Rietkerk et al. 2004a; Wetzel et al. 2005). Moreover, when trees die and fall down on the bog surface, the logs provide a nutrient-rich environment suitable for successful colonization by vascular plants (Agnew et al. 1993). It can thus be concluded that nutrients in the substrate only affect vascular plant growth. Sphagnum decreases this nutrient availability, while vascular plants increase nutrient release rates in the substrate. Both functional groups thus modify the environment in opposite directions. If vascular plants increase in density, they modify the environment toward better growing conditions for themselves, and they can better counteract nutrient depleting effects of modification by Sphagnum. If Sphagnum increases in density it makes growing conditions for vascular plants worse.

\section{Temperature}

The living top layer $(<5 \mathrm{~cm})$ of the Sphagnum carpet tends to be relatively warm, thereby lengthening its growing season (Clymo and Hayward 1982; Van Breemen 1995). On the other hand, Sphagnum peat conducts heat poorly. Vascular plants mainly extend their root system in the upper peat layer (Backéus 1986; Laiho and Finer 1996; Gunnarsson and Rydin 1998). Since vascular plant growth depends on the functioning of belowground roots, a substrate that is dominated by Sphagnum peat leaves a relatively short growing season for vascular plants (Williams 1970; Van Breemen 1995). So, the characteristics of the living Sphagnum layer lengthen the growing season for Sphagnum itself, while the peat that is formed by its remains shortens the growing season of vascular plants. So concerning temperature, Sphagnum modifies the environment in a way that positively affects itself, and negatively influences vascular plants.

\section{Linking habitat modification to vegetation patchiness}

In general, competition for resources drives intraspecific competition within functional groups, and therefore negative feedback. However, in bogs, the different pathways to habitat modification (Fig. 2) show that both Sphagnum and vascular plants also modify their habitat toward better growing conditions for themselves, or suppress the other functional group. These positive effects give the possibility of bistability, because with a small change in biota or environment the system may switch between alternate stable states (Odum 1971; Wilson and Agnew 1992). Following Wilson and Agnew (1992), different types of these vegetation switches can be distinguished. A one sided switch (also called type I switch) means that a functional group changes an environmental factor to its own advantage in patches where it is present. Two type I switches may be involved in bogs, namely the modification of temperature and $\mathrm{pH}$ by Sphagnum (Fig. 3). A reaction switch (type II) refers to a process of a functional group changing an environmental factor to its own advantage in patches where it is present, and also changes this factor outside the patch, but in opposite direction. A type II switch in this system involves vascular plants increasing nutrient concentrations in patches where they are present through advective transport, but thereby decreasing nutrient concentrations further away from these patches (Fig. 3). A symmetric switch (type III) means that a functional group changes an environmental factor to its own advantage in its patches, and another functional group simultaneously changes the same environmental factor in its patches, but in the opposite direction. Three type III switches can be distinguished; Sphagnum changes light availability, distance to the water table, and nutrient availability in a way that favors 


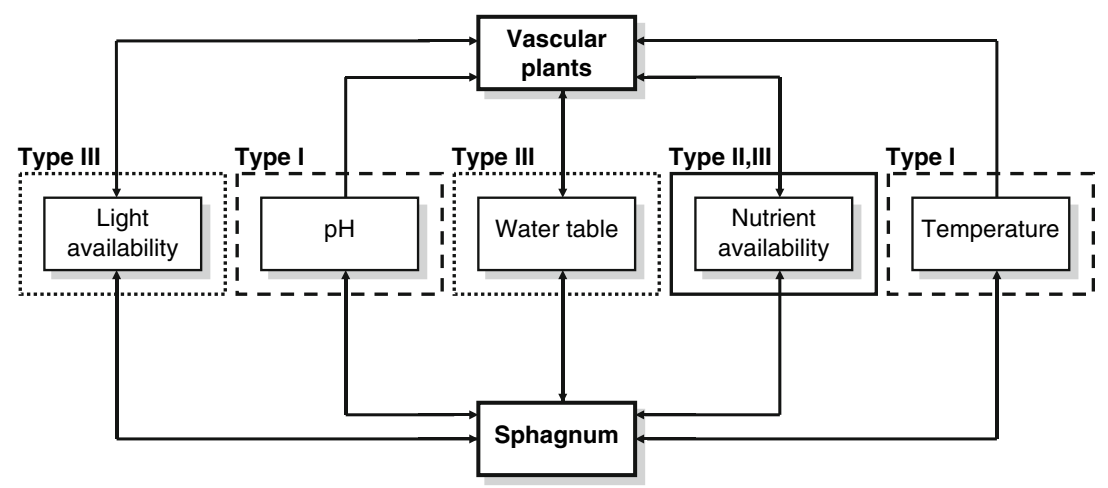

Fig. 3 Vegetation switch analysis of the bog ecosystem. Romans indicate the three different types of switches that are distinguished here (following Wilson and Agnew 1992). I: One sided switches; Sphagnum changes temperature and $\mathrm{pH}$ in a way that stimulates their own growth in the patch where they are present. II: Reaction switch; Vascular plants increase

their own growth, while vascular plants do the same by modifying these environmental variables in the opposite directions (Fig. 3).

The concept of different types of vegetation switches is useful, because it enables separation of local and longer-range processes. The type I and type III switches only act within vegetation patches, and therefore agree with our definition of local. Hence, they cannot explain spatial regularity in vegetation patchiness (Wilson and Agnew 1992; Rietkerk et al. 2004a, b). The type II switch results from a shortrange positive effect (inside the vegetation patch), and a longer-range (outside this patch) negative effect. Therefore, this type of switch can explain spatial regularity in vegetation patterns, which in turn may indicate proximity to catastrophic thresholds in ecosystems (Rietkerk et al. 2004b).

\section{A general model on bog dynamics}

As an illustration, we will now include the discussed interactions between Sphagnum, vascular plants and the bog environment in an analytical bog model, disentangling the effect of the previously discussed local and longer-range processes on self-organized patchiness and stability of bog ecosystems. The simplifying assumption of considering functional vegetation groups enables the inclusion of Sphagnum and the effects of habitat modification in a simple and generic way in the model of Rietkerk et al. (2004a). nutrient concentrations in the patches where they are present, but thereby decreasing nutrient concentrations at further distances. III: Symmetric switches; Sphagnum changes light availability, water table, and nutrient availability in a way that favors their own growth. Vascular plants do the same, by modifying these variables in the opposite directions

In the following, we investigate how this extension affects model results (See Appendix for all analytical details).

Competition between Sphagnum and vascular plants in bogs occurs mainly through habitat modification (Fig. 2). Modeling competition through modification of biotic or abiotic habitat components requires a different approach than the standard competition model (e.g., Eppinga et al. 2006). In the standard Lotka-Volterra approach, the relative loss rate (i.e., the damage that is exerted by 1 unit of biomass of the competitor) is modeled as a linearly increasing function of biomass (Fig.4a). However, the analysis presented here suggests that vascular plants are negatively affected by modification of $\mathrm{pH}$ and temperature by Sphagnum (Fig. 2); therefore we assume that provided that Sphagnum is present, vascular plant biomass is lost through these effects (Fig. 4a). Also, we model modification by both functional groups of water table, nutrients and light availability in a different way than Lotka-Volterra competition. For these factors, the damage that is exerted by the competitor is saturating, meaning that there is a decreasing relative competitive effect with increasing density of the functional group.

Simulations of the Rietkerk et al. (2004a) model (from here referred to as the original model) show that vascular plant biomass develops in a spatially regular structure (Rietkerk et al. 2004a; Fig. 4b). However, apart from spatial regularity, other conspicuous features of vegetation patterns in bogs are 

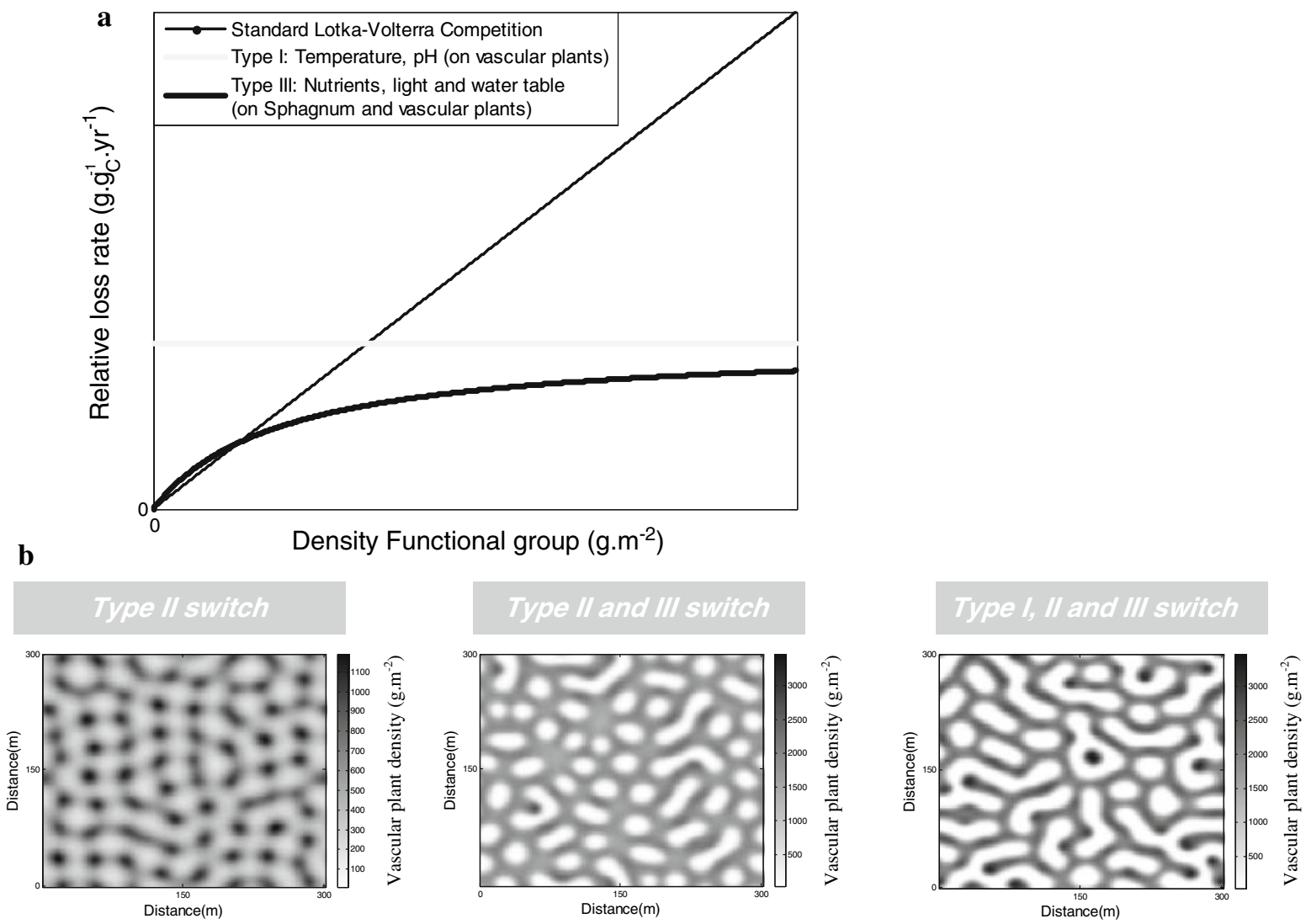

Fig. 4 (a) Conceptual graph showing the difference between competition caused by type I and type III switches and the standard Lotka-Volterra approach. The relative loss rate indicates the damage that is exerted by 1 unit of biomass of the competitor. In the standard Lotka-Volterra approach, the relative loss rate increases linearly with biomass. For type I competition the relative loss rate is constant, for type III competition it is saturating. (b) Effect of vegetation switches on vegetation patchiness. The model of Rietkerk et al. (2004a)

the sharp boundaries between different functional groups (Fig. 1). In the original model nutrient accumulation by vascular plants induces a type II switch, which drives the formation of a spatially regular pattern but does not drive the formation of sharply bounded patches of vascular plants (Rietkerk et al. 2004a; Fig. 4b).

If we now include competition between Sphagnum and vascular plants inducing a type III switch, we see that because of this switch, sharper transitions occur in the vegetation pattern, as observed in the field (Fig. 4b). This result is in compliance with the assertion that a type III switch can sharpen vegetation boundaries and can create a stable vegetation mosaic included only a type II switch, which drives the formation of a regular pattern, but not sharp transitions between vegetation types (left panel, $N_{i n}=1.4 \mathrm{~g}_{\mathrm{N}} \cdot \mathrm{m}^{-2} \cdot \mathrm{yr}^{-1}$ ). Extending this model by incorporation of competition between Sphagnum and vascular plants inducing a type III switch sharpens vegetation boundaries (middle panel, $N_{i n}=3.4 \mathrm{~g}_{\mathrm{N}} \cdot \mathrm{m}^{-2} \cdot \mathrm{yr}^{-1}$ ). When the model is further extended with Sphagnum affecting vascular plants in a way that induces a type I switch, the Sphagnum patches expand (right panel $N_{i n}=3.4 \mathrm{~g}_{\mathrm{N}} \cdot \mathrm{m}^{-2} \cdot \mathrm{yr}^{-1}$ )

(Wilson and Agnew 1992). If we subsequently introduce the type I switch exerted by Sphagnum in the model, the Sphagnum patches in the pattern expand (Fig. 4b), which is in compliance with the findings of Wilson and Agnew (1992). At a certain point in time, however, the expansion of Sphagnum patches in the model stops, meaning that at this moment the type II and type III switches outweigh the effect of the type I switch.

Apart from the self-organized vegetation patchiness becoming more pronounced, the parameter region in which hysteresis occurs increases (Fig. 5). In most of this region, vascular plants could stably exist in the original model, but can now become 
Fig. 5 Bifurcation diagrams. Full black lines depict mean field equilibria, dashed black lines patterned equilibria. The black dotted line is a separatrix. (a) The original model by Rietkerk et al. (2004a), which only contains the nutrient accumulation mechanism. Along a gradient of nutrient input, four situations can be distinguished; $A$ : Low nutrient input where vascular plants cannot exist. $B$ : Region of nutrient input rates where no vascular plants or vascular plants growing in a pattern are both stable equilibria. $C$ : Nutrient input range where vascular plants always exist and grow in patterns. $D$ : Nutrient input region where vascular plants always exist, forming a homogeneous cover $C B_{1}$ is the catastrophic bifurcation point where vascular plants go extinct. $C B_{2}$ is the catastrophic bifurcation point where vascular plants always invade the system. (b) The original model extended with Sphagnum and habitat modification by Sphagnum and vascular plants. In parameter region $E$, there is bistability between homogeneous Sphagnum cover and homogenous vascular plant cover. The separatrix denotes the basins of attraction of the equilibria. Ecosystem states above the separatrix evolve toward the equilibrium with vascular plants; ecosystem states below the separatrix evolve to the equilibrium without vascular plants. $C B$ is the catastrophic bifurcation point where vascular plants go extinct

excluded by Sphagnum because of the type I and type III switches. Note that the vegetation state of only Sphagnum is a stable equilibrium for the entire parameter region examined (Fig. 5b). However, the negative slope of the separatrix shows that when nutrient input increases, the basin of attraction of this equilibrium becomes smaller (Fig. 5b). This means that a smaller amount of vascular plant biomass is needed to invade the system. So, local habitat modification and scale-dependent feedback synergistically affect pattern formation and stability in the model system (Figs. 4, 5). The model results show that when approaching the catastrophic bifurcation point, a distinct sequence of different self-organized vegetation patterns can be observed (Fig. 5).

On slopes (See Appendix for modeling details), the model generates string and flark patterns (Fig. 6). Similar to the simulations on flat surfaces, vascular plants become more pronouncedly present with increasing nutrient input. First, the number of the vascular plant dominated strings increases, and the width of Sphagnum dominated flarks decreases. If nutrient input is further increased, the width of the strings increases (Fig. 6).

\section{The impact of future climate change on bogs}

The literature survey presented here suggests that the pivotal environmental variables in bogs are subject to
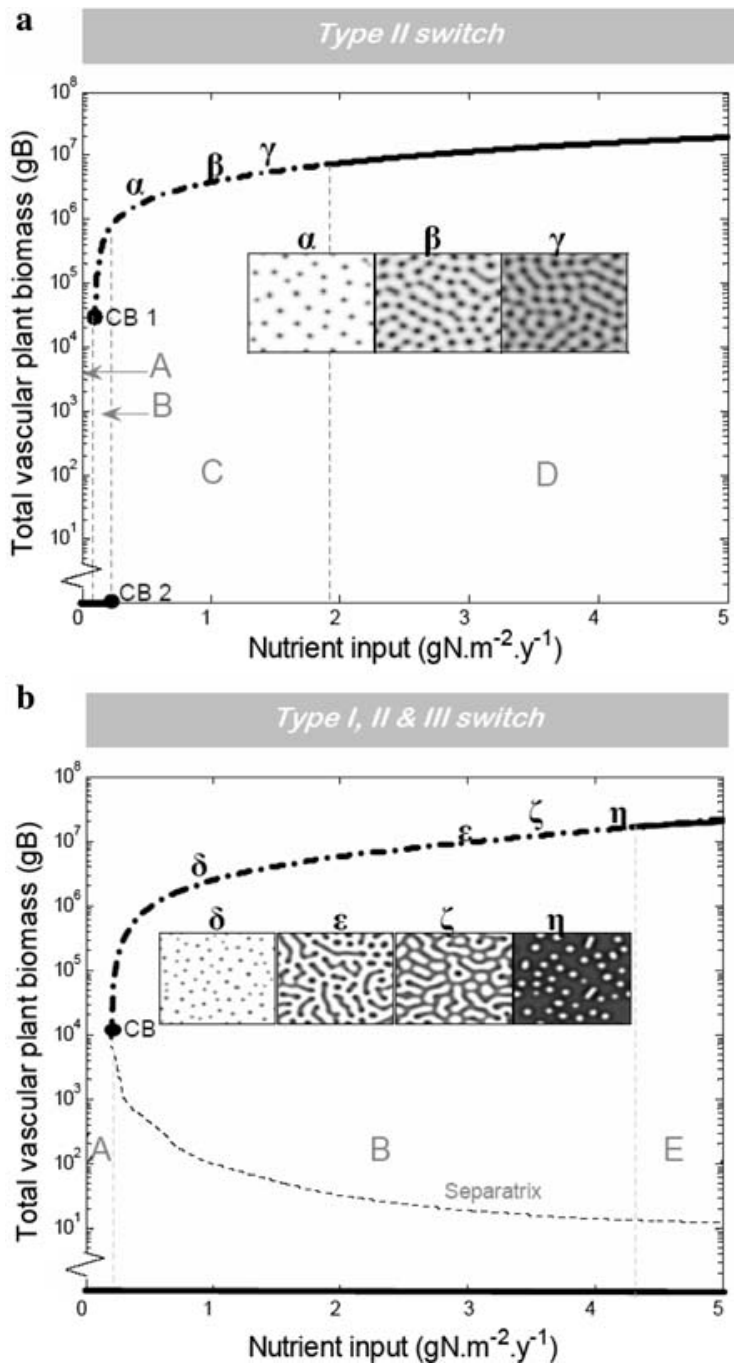

modification by Sphagnum and vascular plants. These processes could have an important effect on the vegetation patchiness and stability of bogs. The analysis revealed that both local and spatial vegetation switches might be involved in the abrupt transitions in vegetation and surface structure of bog ecosystems. These transitions can be abrupt in space (vegetation patchiness) and time (catastrophic shifts). The model results suggest that because of incorporation of local habitat modification, vegetation boundaries become sharper and also the parameter region of bistability drastically increases, suggesting that local and longer-range interactions between the vegetation and the bog environment synergistically govern pattern formation and stability. 


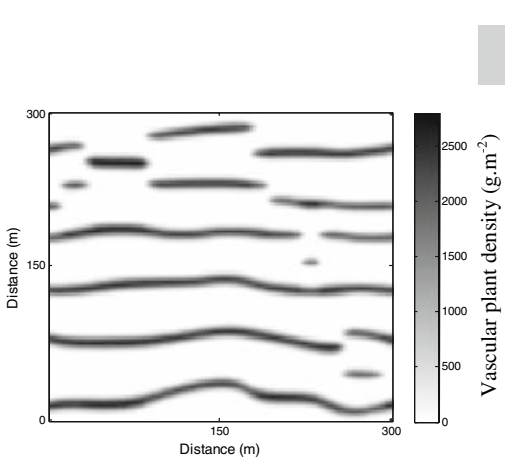

Fig. 6 Linear vegetation patterns emerging on bog slopes. Slopes are mimicked by modeling unidirectional water flow (cf. Rietkerk et al. 2004a). With increasing nutrient input rate, vascular plants increase in dominance. First, the main mode of expansion is an increase in the number of vascular plant

It would be interesting to expand our current model to examine how expected increases in mean annual temperature and precipitation in the boreal zone (Houghton et al. 1995; Hadley Centre Coupled Model Version 3 (HadCM3)) may alter the pivotal environmental variables in bogs. Both Sphagnum and vascular plants can amplify such external changes (Fig. 2). For example, an increase in temperature lengthens the growing season and increases mineralization rates (Aerts et al. 1992; Gunnarsson et al. 2004), which favors vascular plants (Backéus 1985). The accompanying decrease in Sphagnum might be self-enforcing because the temperature switch becomes less effective; a smaller proportion of Sphagnum in the peat layer leads to warmer conditions in the rooting zone of vascular plants, which further lengthens the growing season of vascular plants. An accompanying amplifying effect could be that this increasing vascular plant density generates higher nutrient availability because of the nutrient switch. The latter switch could also amplify increased nutrient availability via atmospheric deposition (Gunnarsson et al. 2004). Moreover, at high atmospheric deposition rates, Sphagnum is not capable of intercepting all nutrients (Lamers et al. 2000; Berendse et al. 2001; Malmer et al. 2003), meaning that nutrients will leach into the rooting zone of vascular plants (Aerts et al. 1992). Our current model results suggest that a Sphagnum dominated bog becomes more susceptible for invasion by vascular plants with increasing nutrient input (Fig. 5b). This result is in compliance with the notion that increased dominated strings. With nutrient input rates increasing further, the width of the individual strings increases. Nutrient input rates were set as follows; Left Window: $1.4 \mathrm{~g}_{\mathrm{N}} \cdot \mathrm{m}^{-2} \cdot \mathrm{yr}^{-1}$ Middle Window: $2.4 \mathrm{~g}_{\mathrm{N}} \cdot \mathrm{m}^{-2} \cdot \mathrm{yr}^{-1}$ Right Window: $3.4 \mathrm{~g}_{\mathrm{N}} \cdot \mathrm{m}^{-2} \cdot \mathrm{yr}^{-1}$

$\mathrm{N}$-deposition could be one reason for the decrease in Sphagnum and rapid expansion of vascular plants that has been observed in many bogs in recent decades (Aaby 1994; Frankl and Schmeidl 2000; Gunnarsson et al. 2002; Malmer et al. 2003).

On the other hand, increases in precipitation may lead to a higher water table, favoring the more pronounced hollow species of Sphagnum (Belyea and Malmer 2004), which in turn can stimulate further submergence through the water table switch. Very high water tables can lead to substantial dieback of higher vascular plants (Gunnarsson and Rydin 1998). So, the response of bogs to future climatic changes is not straightforwardly determined, because it involves the study of the relative importance of different processes possibly inducing vegetation switches.

Another difficulty in such predictions is that the relative importance of different processes (Fig. 2) is probably site-specific. For example, in relatively nutrient-rich mires, Malmer et al. (2003) found that the competition between Sphagnum and vascular plants for light was more important than for nutrients, while we expect the opposite to be true for the oligotrophic patterned bogs in the Vasyugan area in Siberia.

Our model results include linear patterning on slopes (Fig. 6), as is also found in models simulating local changes in hydrology (Swanson and Grigal 1988; Couwenberg 2005; Couwenberg and Joosten 2005). These models have the advantage of predicting linear patterning in both bogs and fens. On the other hand, our model simulating local resource 
accumulation has the advantage of predicting patterning on both slopes and flatter parts of peatland bogs dominated by Sphagnum. Formulation of such multiple independent hypotheses about possible different mechanisms driving the spatial self-organization of bogs will benefit the interpretations of selforganized vegetation patterns in bogs (Belyea and Lancaster 2002), which is necessary to identify whether these vegetation patterns can serve as indicators of proximity to catastrophic shifts or climate change.

Studying the interactions that drive pattern formation in peatlands can contribute to a better understanding of the ecosystems functioning in general. The interactions between Sphagnum and vascular plants may induce vegetation switches that can drive such pattern formation. In general, these switches are expected to be important driving forces behind the rapid and nonlinear responses of peatland vegetation to climatic changes (Frankl and Schmeidl 2000; Ohlson et al. 2001; Belyea and Malmer 2004). Hence, interactions between Sphagnum and vascular plants exert a strong influence on the carbon accumulation rate in peatlands (Malmer et al. 2003), and therefore need to be taken into account in future predictions on the response of these systems to climatic changes.

Acknowledgments The authors thank Wladimir Bleuten and Elena Lapshina for sharing their photographs. Aat Barendregt, Yuki Fujita, Sonia Kéfi, Jasper Van Belle, Ton Verkroost and three anonymous reviewers provided comments that improved the manuscript. The research of MBE and MR is supported by a VIDI grant from the Research Council Earth and Life Sciences of the Netherlands Organization of Scientific Research to MR.

\section{Appendix: Analytical details of the model}

The competition effect of Sphagnum on vascular plants exhibiting a type I switch (Fig. 4a) is modeled by the following term:

$c_{B S} S$

In which $S$ is the density of Sphagnum (units: $\mathrm{g}_{\mathrm{S}} \cdot \mathrm{m}^{-2}$ ) and $c_{B S}$ the type I coefficient, representing the relative amount of vascular plant biomass that cannot grow because of the acidifying and substratetemperature decreasing effect of Sphagnum
$\left(\mathrm{g}_{\mathrm{B}} \cdot \mathrm{g}_{\mathrm{S}}^{-1} \cdot \mathrm{yr}^{-1}\right)$. Now, both Sphagnum and vascular plants are affected by competition that induces type III switches, which can be converged in the following term in the equation for vascular plant growth:

$\frac{\kappa_{B S} B S}{H_{B}+B}$

where $B$ is the vascular plant density $\left(\mathrm{g}_{\mathrm{B}} \cdot \mathrm{m}^{-2}\right), \kappa_{B S}$ is the type III coefficient for vascular plants, representing the relative amount of vascular plant biomass that cannot grow because of the overgrowing (light) and submergence stimulating (water table) and available nutrient decreasing effect of Sphagnum $\left(\mathrm{g}_{\mathrm{B}} \cdot \mathrm{g}_{\mathrm{S}}^{-1} \cdot \mathrm{yr}^{-1}\right) . H_{B}$ is the type III half-saturation density for vascular plants $\left(\mathrm{g}_{\mathrm{B}} \cdot \mathrm{m}^{-2}\right)$.

In similar vein, we derive the type III competition term affecting Sphagnum growth:

$\frac{\kappa_{S B} S B}{H_{S}+S}$

With $\kappa_{S B}$ being the type III feedback coefficient for Sphagnum $\left(\mathrm{g}_{\mathrm{S}} \cdot \mathrm{g}_{\mathrm{B}}^{-1} \cdot \mathrm{yr}^{-1}\right)$, and $H_{S}$ the half-saturation density $\left(\mathrm{g}_{\mathrm{S}} \cdot \mathrm{m}^{-2}\right)$, respectively.

For low atmospheric nutrient input rates, it is reasonable to assume that Sphagnum intercepts all nutrients from atmospheric deposition (Malmer et al. 2003). Assuming a constant deposition rate, we describe Sphagnum development by logistic growth. The lateral expansion of Sphagnum is modeled as a diffusion term (Okubo 1989; cf. Rietkerk et al. 2002; Rietkerk et al. 2004a). Including all terms in the equations for vascular plants, nutrients and height of the water table that were derived in Rietkerk et al. (2004a), we have obtained the following model:

$$
\frac{\partial S}{\partial t}=r_{S} S\left(1-\frac{S}{S_{\max }}\right)-\frac{\kappa_{S B} S B}{H_{S}+S}+D_{S}\left(\frac{\partial^{2} S}{\partial x^{2}}+\frac{\partial^{2} S}{\partial y^{2}}\right)
$$

$$
\begin{aligned}
\frac{\partial B}{\partial t}=r_{B}[N] f(h(H)) B-d B-b B-c_{B S} S-\frac{\kappa_{B S} B S}{H_{B}+B} \\
+D_{B}\left(\frac{\partial^{2} B}{\partial x^{2}}+\frac{\partial^{2} B}{\partial y^{2}}\right)
\end{aligned}
$$




$$
\begin{aligned}
\frac{\partial[N]}{\partial t}= & \frac{N_{i n}-u[N] B f(h(H))+\frac{d u B}{r_{B}}-r_{N} N-[N] \theta \frac{\partial H}{\partial t}}{H \theta} \\
& +D_{N}\left(\frac{\partial^{2}[N]}{\partial x^{2}}+\frac{\partial^{2}[N]}{\partial y^{2}}\right)+\frac{k}{\theta}\left(\frac{\partial}{\partial x}\left([N] \frac{\partial H}{\partial x}\right)\right. \\
& \left.+\frac{\partial}{\partial y}\left([N] \frac{\partial H}{\partial y}\right)\right) \\
\frac{\partial H}{\partial t}= & \frac{p}{\theta}-\frac{t_{v} B f(h(H))}{\theta}-\frac{e f(h(H))}{\theta} \\
& +\frac{k}{\theta}\left(\frac{\partial}{\partial x}\left(H \frac{\partial H}{\partial x}\right)+\frac{\partial}{\partial y}\left(H \frac{\partial H}{\partial y}\right)\right)
\end{aligned}
$$

in which $r_{s}$ is a Sphagnum growth parameter $\left(\mathrm{yr}^{-1}\right)$, $S_{\max }$ is the carrying capacity of Sphagnum $\left(\mathrm{g}_{\mathrm{s}} \cdot \mathrm{m}^{-2}\right)$, $[\mathrm{N}]$ is the nutrient concentration in the groundwater $\left(\mathrm{g}_{\mathrm{N}} \cdot \mathrm{m}^{-3}\right), H$ is the hydraulic head $(\mathrm{m}), t$ is time $(\mathrm{yr})$, $r_{B}$ is the vascular plant growth parameter $\left(\mathrm{m}^{3} \cdot \mathrm{g}_{\mathrm{N}}^{-1} \cdot \mathrm{yr}^{-1}\right), d$ is the vascular plant mortality rate $\left(\mathrm{yr}^{-1}\right), b$ is the rate of nutrient loss from the landscape $\left(\mathrm{yr}^{-1}\right), N_{i n}$ is the nutrient input rate $\left(\mathrm{g}_{\mathrm{N}} \cdot \mathrm{m}^{-2} \cdot \mathrm{yr}^{-1}\right), u$ is a plant uptake parameter $\left(\mathrm{m}^{3} \cdot \mathrm{g}_{\mathrm{B}}^{-1} \cdot \mathrm{yr}^{-1}\right), r_{N}$ is a nutrient loss parameter $\left(\mathrm{yr}^{-1}\right)$, $p$ is the precipitation rate $\left(\mathrm{m} \cdot \mathrm{yr}^{-1}\right), \theta$ is soil porosity (dimensionless), $t_{v}$ depicts the vascular plant transpiration rate $\left(\mathrm{m}^{3} \cdot \mathrm{g}_{\mathrm{B}}^{-1} \cdot \mathrm{yr}^{-1}\right), e$ is an evaporation parameter $\left(\mathrm{m} \cdot \mathrm{yr}^{-1}\right), D_{S}$ is the diffusion coefficient for Sphagnum biomass $\left(\mathrm{m}^{2} \cdot \mathrm{yr}^{-1}\right), D_{B}$ is the diffusion coefficient for vascular plant biomass $\left(\mathrm{m}^{2} \cdot \mathrm{yr}^{-1}\right), D_{N}$ is the diffusion coefficient for nutrients $\left(\mathrm{m}^{2} \cdot \mathrm{yr}^{-1}\right)$, and $k$ is the hydraulic conductivity $\left(\mathrm{m} \cdot \mathrm{yr}^{-1}\right) \cdot f(h(H))$ is a dimensionless soil water stress function that is defined as follows:

$$
\begin{aligned}
& f(h(H))=1, \quad H-z \geq h_{1} \\
& f(h(H))=0, \quad H-z \leq h_{2} \\
& f(h(H))=\frac{H-z-h_{2}}{h_{1}-h_{2}}, \quad h_{1} \leq H-z \leq h_{2}
\end{aligned}
$$

in which $h_{1}$ is the pressure head below which soil water stress occurs (m), $h_{2}$ is the rooting depth of vascular plants $(\mathrm{m})$, and $z$ is a reference height $(\mathrm{m})$. All parameter values follow Rietkerk et al. (2004a). To the newly introduced parameters, we assigned the following values: $r_{s}=0.2, S_{\max }=800, D_{S}=0.2$, $\kappa_{B S}=0.5, c_{B S}=0.1, \kappa_{S B}=0.1, H_{B}=800, H_{S}=300$ (Van Breemen 1995; Ohlson et al. 2001). The value of $N_{\text {in }}$ is varied for the simulations presented in the figures, values are given in the captions. In model runs simulating vegetation dynamics on a bog slope, water flow was set in one direction (cf. Rietkerk et al. 2004a).

\section{References}

Aaby B, (1994) Monitoring Danish raised bogs. In: Grünig A (ed) Mires and man-mire conservation in a densely populated country-the Swiss experience. Swiss Federal Institute for Forest, Snow and landscape Research, Birmensdorf, Switzerland, pp 284-300

Aerts R, Wallén B, Malmer N, (1992) Growth-limiting nutrients in Sphagnum dominated bogs subject to low and high atmospheric nitrogen supply. J Ecol 80:131-140

Agnew ADQ, Wilson JB, Sykes MT (1993) A vegetation switch as the cause of a forest mire ecotone in NewZealand. J Veg Sci 4:273-278

Alexandrov GA, Logofet DO (1994) Raised mire succession as modeled by multiple equilibria and dissipative structures. In: Mitsch WJ (ed) Global wetlands: old world and new. Elsevier, Amsterdam, pp 585-592

Backéus I (1985) Aboveground production and growth dynamics of vascular bog plants in Central Sweden. Acta Phytogeographica Suecica 74:5-102

Backéus I (1986) Production and depth distribution of fine roots in a boreal open bog. Ann Bot Fenn 27:261-265

Backéus I (1989) Flarks in the Maloti, Lesotho. Geogr Ann A 71:105-111

Belyea LR (1996) Separating the effects of litter quality and microenvironment on decomposition rates in a patterned peatland. Oikos 77:529-539

Belyea LR, Clymo RS (2001) Feedback control of the rate of peat formation. Proc R Soc Lond B 268:1315-1321

Belyea LR, Lancaster J (2002) Inferring landscape dynamics of bog pools from scaling relationships and spatial patterns. $\mathrm{J}$ Ecol 90:223-234

Belyea LR, Malmer N (2004) Carbon sequestration in peatland: patterns and mechanisms of response to climate change. Glob Change Biol 10:1043-1052

Berendse F, Van Breemen N, Rydin H et al (2001) Raised atmospheric $\mathrm{CO}_{2}$ levels and increased $\mathrm{N}$ deposition cause shifts in plant species composition and production in Sphagnum bogs. Glob Change Biol 7:591-598

Bertness MD, Trussel GC, Ewanchuk PJ et al (2002) Do alternate community stable states exist on rocky shores in the Gulf of Maine? Ecology 83:3434-3448

Boatman DJ, Tomlinson RW (1973) The silver flowe. I. Structural and hydrological features of Birshie Bog and their bearing on pool formation. J Ecol 61:653-666

Bragazza L, Alber R, Gerdol R (1998) Seasonal pore water chemistry in hummocks and hollows in a poor-mire in the southern Alps (Italy). Wetlands 18:320-328

Bridgham SD, Johnston CA, Pastor J et al (1995) Potential feedbacks of northern wetlands on climate-change-an outline of an approach to predict climate-change impact. Bioscience 45:262-274 
Carpenter SR (2001) Alternate states of ecosystems: evidence and its implications. In: Press MC, Huntly N, Levin S (eds) Ecology: achievement and challenge. Blackwell, London, pp 357-381

Casparie WA (1972) Bog development in southeastern Drenthe, the Netherlands. Vegetatio 25:1-271

Charman DJ (2002) Peatlands and environmental change. Wiley, London

Clymo RS (1964) The origin of acidity in Sphagnum bogs. Bryology 67:427-431

Clymo RS (1970) The growth of Sphagnum: methods of measurement. J Ecol 58:13-49

Clymo RS, Hayward PM (1982) The ecology of Sphagnum. In: Smith AJE (ed) Bryophyte ecology. Chapman and Hall, London, pp 229-289

Coulson JC, Butterfield J (1978) An investigation of the biotic factors determining the rates of plant decomposition on blanket bog. J Ecol 66:631-650

Couwenberg J (2005) A simulation model of mire patterningrevisited. Ecography 28:653-661

Couwenberg J, Joosten H (2005) Self-organization in raised bog patterning: the origin of microtope zonation and mesotope diversity. J Ecol 93:1238-1248

Eppinga MB, Rietkerk M, Dekker SC et al (2006) Accumulation of local pathogens: a new hypothesis to explain exotic plant invasions. Oikos 114:168-176

Fitter AH, Hay RKM (1983) Environmental physiology of plants. Academic Press, London

Foster DR, King GA (1984) Landscape features, vegetation and developmental history of a patterned fen in southeastern Labrador, Canada. J Ecol 72:115-143

Foster DR, King GA, Glaser PH et al (1983) Origin of string patterns in boreal peatlands. Nature 306:256-258

Frankl R, Schmeidl H (2000) Vegetation change in a South German raised bog. Ecosystem engineering by plant species, vegetation switch or ecosystem level feedback mechanisms? Flora 195:267-276

Frenzel B (1983) Mires-repositories of climatic information or self-perpetuating ecosystems. In: Gore AJP (ed) Mires: swamp, bog, fen, and moor, Ecosystems of the world 4. Elsevier, New York, pp 35-67

Glaser PH (1987) The development of streamlined bog islands in the continental interior of North America. Arctic Alpine Res 19:402-413

Glaser PH (1992) Ecological development of patterned peatlands. In: Wright HE Jr, Coffin BA, Aaseng NE (eds) The patterned peatlands of Minnesota. University of Minnesota press, Minneapolis, pp 27-42

Glaser PH, Siegel DI, Reeve AS et al (2004) Tectonic drivers for vegetation patterning and landscape evolution in the Albany River region of the Hudson Bay Lowlands. J Ecol 92:1054-1070

Glaser PH, Wheeler GA, Gorham E et al (1981) The patterned mires of the Red Lake Peatland, northern Minnesota: vegetation, water chemistry and landforms. J Ecol 78:1021-1048

Gorham E (1991) Northern peatlands: role in the carbon cycle and probable responses to climatic warming. Ecol Appl 1:182-195
Gorham E, Underwood JK, Martinand FB et al (1986) Natural and anthropogenic causes of lake acidification in Novia Scotia. Nature 324:451-453

Gunnarsson U, Granberg G, Nilsson M (2004) Growth, production and interspecific competition in Sphagnum: effects of temperature, nitrogen and sulphur treatments on a boreal mire. New Phytol 2:349-359

Gunnarsson U, Malmer N, Rydin H (2002) Dynamics or constancy in Sphagnum dominated mire ecosystems? A 40year study. Ecography 25:685-704

Gunnarsson U, Rydin H (1998) Demography and recruitment of Scots pine on raised bogs in eastern Sweden and relationships to microhabitat differentiation. Wetlands 18:133-141

Gunnarsson U, Rydin H, Sjörs H (2000) Diversity and pH changes after 50 years on the boreal mire Skattlösbergs Stormosse, Central Sweden. J Veg Sci 11:277-286

Hayward PM, Clymo RS (1983) The growth of Sphagnum: experiments on, and simulation of, some effects of light flux and water-table depth. J Ecol 71:845-863

Heijmans MMPD, Klees H, Berendse F (2002) Competition between Sphagnum magellanicum and Eriophorum angustifolium as affected by raised $\mathrm{CO}_{2}$ and increased $\mathrm{N}$ deposition. Oikos 97:415-425

Heinselman ML (1963) Forest sites, bog processes and peatland types in the Glacial Lake Agassiz region, Minnesota. Ecol Monograph 33:327-374

Hemond HF (1980) Biogeochemistry of Thoreau's bog, Concord, Massachusetts. Ecol Monograph 50:507-526

Hilbert DW, Roulet N, Moore T (2000) Modelling and analysis of peatlands as dynamical systems. J Ecol 88:230-242

Hobbie SE (1996) Temperature and plant species control over litter decomposition in Alaskan tundra. Ecol Monogr 66:503-522

Houghton JTL, Meira Filho LG, Callender BA et al (eds) (1995) Climate change 1995:the science of climate change. Cambridge University Press, Cambridge

Ingram HAP (1983) Hydrology. In: Gore AJP (ed) Ecosystems of the World 4A. Mires: Swamp, Bog, Fen and Moor. Elsevier, New York, pp 67-158

Ivanov KE (1981) Water movement in mirelands (Vodoobmen v bolotnykh landshaftakh). Trans. by Thomson A, Ingram HAP. Academic Press, London

Johnson LC, Damman AWH (1993) Decay and its regulation in Sphagnum peatlands. Adv Bryol 5:249-296

Kuznetsov Y (1995) Elements of applied bifurcation theory. Springer-Verlag, New York

Laiho R, Finer L (1996) Change in root biomass after waterlevel drawdown on pine mires in southern Finland. Scand J Forest Res 11:251-260

Lamers LPM, Bobbink R, Roelofs JGM (2000) Natural nitrogen filter fails in polluted raised bogs. Glob Change Biol 6:583-586

Lewontin RC (1969) The meaning of stability. Brookhaven Symp Biol 22:13-24

Limpens J, Berendse F, Klees H (2003) N deposition affects N availability in interstitial water, growth of Sphagnum and invasion of vascular plants in bog vegetation. New Phytol 157:339-347 
Loehle C (1989) Catastrophe theory in ecology: a critical review and an example of the butterfly catastrophe. Ecol Model 49:125-152

Logofet DO Alexandrov GA (1988) Interference between Mosses and Trees in the framework of a dynamic model of carbon and nitrogen cycling in a mesotrophic bog ecosystem. In: Mitsch W, Straskaba M, Jorgensen SE (eds) Wetland Modelling (Developments in Environmental Modelling, v.12). Elsevier, Amsterdam, pp 55-67

Malmer N (1962) Studies on mire vegetation in the Archaean area of southwestern Götaland. I. Vegetation and habitat conditions on the Åkhult mire. Opera Botanica 7:1-322

Malmer N, Svensson BM, Wallén B (1994) Interactions between Sphagnum mosses and field layer vascular plants in the development of peat-forming systems. Folia Geobot Phytotx 29:483-496

Malmer N, Albinsson C, Svensson BM et al (2003) Interferences between Sphagnum and vascular plants: effects on plant community structure and peat formation. Oikos 100:469-482

Mark AF, Johnson PN, Dickinson KJM et al (1995) Southern hemisphere patterned mires, with emphasis on southern New Zealand. J Roy Soc New Zeal 25:23-54

Marschner H (1995) Mineral nutrition of higher plants. Academic Press, London

Meijer ML, Hosper H (1997) Effects of biomanipulation in the large and shallow Lake Wolderwijd, The Netherlands. Hydrobiologia 342:335-349

Moore PD (1977) Stratigraphy and pollen analysis of Claish Moss, north-west Scotland:significance for the origin of surface-pools and forest history. J Ecol 65:365-397

Murray KJ, Tenhunen JD, Nowak RS (1993) Photoinhibition as a control on photosynthesis and production of Sphagnum mosses. Oecologia 96:200-207

Nungesser MK (2003) Modelling microtopography in boreal peatlands: hummocks and hollows. Ecol Model 165:175207

Odum HT (1971) Environment, power, and society. Wiley, New York

Ohlson M, Økland RH, Nordbakken J-F et al (2001) Fatal interactions between Scots pine and Sphagnum mosses in bog ecosystems. Oikos 94:425-432

Økland RH (1990) A phytoecological study of the mire Northern Kisselbergmosen, SE Norway. II. Identification of gradients by detrended (canonical) correspondence analysis. Nord J Bot 10:79-108

Okubo A (1989) Diffusion and ecological problems: mathematical models. Springer, New York

Redbo-Torstensson P (1994) Variation in plastic response to a salinity gradient within a population of the halophytic plant Spergularia marina. Oikos 70:349-358

Reeve AS, Siegel DI, Glaser PH (1996) Geochemical controls on peatland pore-water from the Hudson Bay Lowlands: a multivariate and statistical approach. J Hydrol 181:285-304

Ricker WE (1963) Big effects from small causes: two examples from fish population dynamics. J Fish Res Bd Can 20:257-264

Rietkerk M, Boerlijst MC, Van Langevelde F et al (2002) Selforganization of vegetation in arid ecosystems. Am Nat 160:524-530
Rietkerk M, Dekker SC, Wassen MJ et al (2004a) A putative mechanism for bog patterning. Am Nat 163:699-708

Rietkerk M, Dekker SC, De Ruiter PC et al (2004b) Selforganized patchiness and catastrophic shifts in ecosystems. Science 305:1926-1929

Rutter AJ (1963) Studies in the water relations of Pinus sylvestris in plantation conditions, I, Measurements of rainfall and interception. J Ecol 51:191-203

Rydin H, Clymo RS, (1989) Transport of carbon and phosphorus-compounds about Sphagnum. Proc R Soc Lond B 237:63-84

Rydin H, McDonald AJS (1985) Tolerance of Sphagnum to water level. J Bryol 13:571-578

Sakaguchi Y (1980) On the genesis of banks and hollows in peat bogs: an explanation by a thatch line theory. Bulletin of the Department of Geography University of Tokyo 12:35-58

Scheffer M, Carpenter SR (2003) Catastrophic regime shifts in ecosystems: linking theory to observation. Trends Ecol Evol 18:648-656

Scheffer M, Carpenter SR, Foley JA et al (2001) Catastrophic shifts in ecosystems. Nature 413:591-596

Semenova NM, Lapshina ED (2001) Description of the West Siberian plain. In: Bleuten W, Lapshina ED (eds) Carbon storage and atmospheric exchange by West Siberian peatlands. Department of Physical Geography Utrecht University, Utrecht

Seppäla M, Koutaniemi L (1985) Formation of a string and pool topography as expressed by morphology, stratigraphy and current processes on a mire in Kuusamo, Finland. Boreas 14:287-309

Siegel DI, Glaser PH, So J et al (2006) The dynamic balance between organic acids and circumneutral groundwater in a large boreal peat basin. J Hydrol 320:421-431

Sjörs H (1961) Surface patterns in boreal peatland. Endeavour 20:217-223

Sjörs H (1983) Mires of Sweden. In: Gore AJP (ed) Mires: swamps, bog, fen and moor. Ecosystems of the world 4B. Elsevier, Amsterdam, pp 69-94

Svensson BM (1995) Competition between Sphagnum fuscum and Drosera rotundifolia: a case of ecosystem engineering. Oikos 74:205-212

Swanson DK, Grigal DF (1988) A simulation model of mire patterning. Oikos 53:309-314

Thom R (1975) Structural stability and morphogenesis: an outline of a general theory of models. Benjamin Cummings, Reading, Massachusetts

Van Breemen N (1995) How Sphagnum bogs down other plants. Trends Ecol Evol 10:270-275

Verry ES, Urban NR (1992) Nutrient cycling at Marcell Bog, Minnesota. Suo 43:147-153

Walker D Walker PM (1961) Stratigraphic evidence of regeneration in some Irish bogs. J Ecol 49:169-185

Wallén B, Falkengren-Grerup U, Malmer N (1988) Biomass, productivity and relative rate of photosynthesis of Sphagnum at different water levels. Holarctic Ecol 11:7076

Wetzel PR, Van der Valk AG, Newman S et al (2005) Maintaining tree islands in the Everglades:nutrient redistribution is the key. Front Ecol Environ 3:370-376 
Williams GP (1970) The thermal regime of a Sphagnum peat bog. Proceedings of the Third International Peat Congress, Quebec, pp 195-200

Wilson JB, Agnew ADQ (1992) Positive-Feedback Switches in Plant-Communities. Adv Ecol Res 23:263-336
Yu ZC, Campbell ID, Vitt DH et al (2001) Modelling longterm peatland dynamics. I. Concepts, review, and proposed design. Ecol Model 145:197-210

Zeeman EC (1976) Catastrophe theory. Sci Am 234:65-83 